\title{
Ocorrência de ferrugem (Olivea neotectonae) em plantas de teca no estado de Sergipe
}

\author{
João Basílio Mesquita ; Ítala Tainy Barreto Francisco dos Santos'; Genésio Tâmara Ribeiro ; Mário Jorge Campos \\ dos Santos $^{1}$
}

${ }^{1}$ Universidade Federal de Sergipe, Laboratório de Patologia Florestal, Departamento de Ciências Florestais, Jardim Rosa Elze, sn, CEP: 49100000, São Cristóvão-SE.

Autor para correspondência: João Basílio Mesquita (basilio_mesquita@hotmail.com).

Data de chegada:27/08/2015. Aceito para publicação em: 01/06/2016.

$10.1590 / 0100-5405 / 2121$

A teca (Tectona grandis Linn. F.), é uma espécie pertencente à família Lamiaceae, que possui um grande potencial de exploração. Sua madeira tem alto valor comercial, é utilizada em carpintaria, marcenaria, produção de móveis finos e de peças de uso nobre, especialmente na indústria de construção naval. No Brasil, a teca está presente em diversas regiões, sendo o principal estado o Mato Grosso, onde é cultivada para a extração da madeira, principalmente para a produção de móveis devido à excelente qualidade, resistência, durabilidade e beleza.

A principal doença que afeta a cultura da teca é a ferrugem, causada pelo fungo Olivea neotectonae (T.S. Ramakr. \& K. Ramakr.). A ferrugem provoca desfolha prematura em todas as fases fenológicas da cultura, reduzindo a velocidade de crescimento das plantas, ocasionando redução da taxa fotossintética e consequentemente influenciando na produção de madeira (Arguedas, M. Kurú: Revista Forestal, v. 1, n.1, p.1-16, 2004). O agente causal da ferrugem da teca foi descrito pela primeira vez por Raciborsky em 1990 na Indochina como O. tectonae (Ramakrishnan, T.S. \& Ramakrishnan, K.. Indian Phytopathology, v.2, p.17-19, 1949). Posteriormente, a doença foi registrada em toda a Ásia (Ferrari, J. T. Instituto Biológico, 2011. 6p. Documento Técnico, 09) e no continente americano a doença já foi registrada no Panamá, Costa Rica (Arguedas, M. Kurú: Revista Forestal, v. 1, n.1, p.1-16, 2004), Equador (EPPO, 2005. n.8. http://archives.eppo. int/EPPOReporting/2005/Rse-0508.pdf), Colômbia (Céspedes, P.B. \& Yepes, M.S. Revista Facultad Nacional de Agronomia de Medellín, v.60, n.1, p.3645-3655, 2007), Cuba (Pérez, M. et al. Plant Pathology, v. 58, n. 2, p. 397, 2009) e Austrália (Daly, A.M. et al. Australasian Plant Disease Notes, v.1, p.25-26, 2006).

Em 2009, no município de Sinop/MT verificou-se pela primeira vez em mudas e plantas de teca a presença de sintomas e sinais de ferrugem (Bonaldo, S. M. et al. Summa Phytopathologica, v. 38, n. 3, p.153,

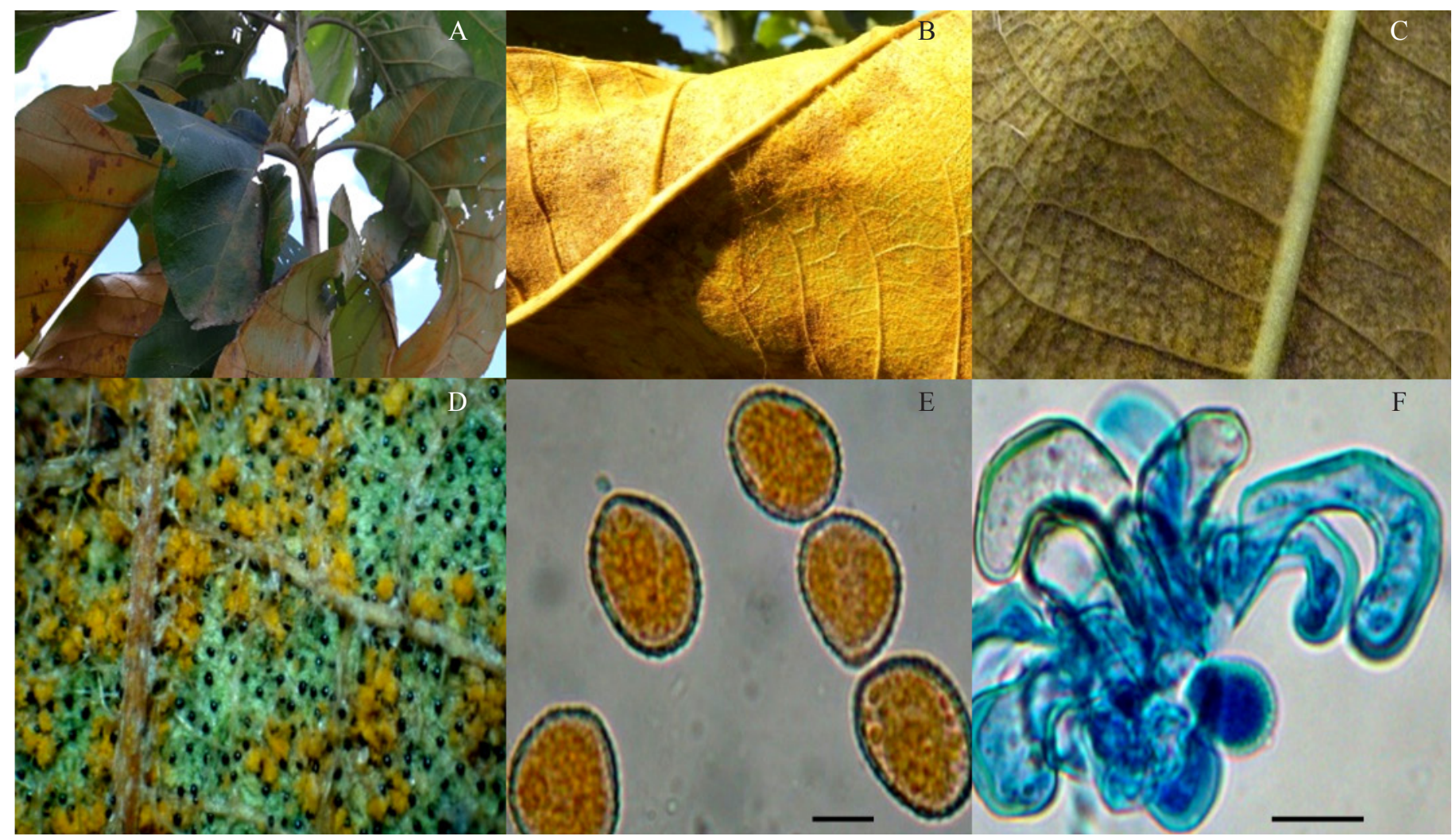

Figura 1. Sintomas de ferrugem em plantas de teca (Tectona grandis.) causados por Olivea neotectonea (A); Pústulas com intensa esporulação na face abaxial do limbo foliar (B); Folha de teca apresentando limbo com aspecto de queima (C); Detalhe das urédias (D); Uredinósporos de Olivea neotectonea $(10 \mu)(\mathrm{E})$; Paráfises $(20 \mu)(\mathrm{F})$. 
2011). No mesmo ano foi relatado a ocorrência de Olivea neotectonae em plantas de teca provenientes do norte do Mato Grosso, Maranhão, Tocantins e São Paulo (Pieri, C. et al. Summa Phytopathologica, v. 37, n. 4, p. 199-201, 2011), e em 2013 no município de Ceres/GO (Velasco, M. F. et al. II Simpósio de Pesquisa e Extensão de Ceres e Vale de São Patrício. Anais, 2014).

Em março de 2015 esta doença foi observada em plantas seminais de teca em diferentes estádios de desenvolvimento, cultivadas no Campus Experimental do Instituto Federal de Educação, Ciência e Tecnologia de Sergipe (IFS) no município de São Cristóvão, Sergipe. A referida doença foi identificada pela presença dos sintomas (Figura 1A), e também dos sinais do patógeno (Figura 1B).

Os sintomas iniciais foram detectados na superfície adaxial das folhas, com pequenas manchas cloróticas de tamanhos variáveis, que com o avanço da doença coalescem e posteriormente recobrem toda a superfície foliar, levando a folha a apresentar um aspecto de queima (Figura C). Como consequência, ocorre queda anormal das folhas baixeiras das plantas infectadas.

$\mathrm{Na}$ superfície abaxial das folhas foram observadas áreas necrosadas com a presença abundante de urédias pulverulentas, de coloração amarelo-alaranjado e com intensa produção de uredinósporos (Figura 1D), que podem ser facilmente disseminados pelo vento. Nas folhas infectadas pelo fungo, foi observada em microscópio óptico, a presença de uredinósporos ovóides, unicelulares, equinulados, apresentando coloração amarelo-alaranjado, com dimensões variando de 19,6-25,6 x 12,3-22,4 $\mu$ (Figura 1E), e ausência de teliósporos. Também foi possível observar paráfises cilíndricas, encurvadas, unidas na base, lisas, paredes engrossadas distalmente, hialinas a marrom-pálidas (Figura 1F).

Com base nas características morfológicas observadas o patógeno foi identificado como Olivea neotectonea (T.S. Ramakrishnan \& K. Ramakrishnan) (Buriticá, P. \& Salazar, M. Revista Facultad Nacional de Agronomia de Medellín, v.60, p.3645- 3655, 2007). Essas características estão de acordo com as descritas por Buriticá \& Salazar (2007) (Revista Facultad Nacional de Agronomia de Medellín, v.60, p.3645-3655), Pieri, C. et al. (2011) (Summa Phytopathologica, v. 37, n. 4, p. 199-201) e Velasco, M. F. et al. (2014) (II Simpósio de Pesquisa e Extensão de Ceres e Vale de São Patrício) e tem como sinônimos: Chaconia tectonae (T.S. Ramakr.\& K. Ramakr.) (Ramakrishnan, T.S. \& Ramakrishnan, K.. Indian Phytopathology, v.2, p.17-19, 1949), Olivea tectonae (T.S. Ramakr.\& K. Ramakr.) (Mulder, J.L. \& Gibson, I.A.S. CMI descriptions of pathogenic Fungi and Bacteria, n.365, 1973), Olivea tectonae (Racib.) (Raciborski, M. Parasitische algen und pilze Javas, v. 1, n. 28, 39p., 1900). Este, trata-se do primeiro relato de Olivea neotectonae no estado de Sergipe. 